\title{
Eosinophilic cystitis, a rare cause of persistent haematuria in a diabetic dog
}

\section{Cistite eosinofílica, uma causa rara de hematúria persistente em um cão diabético}

\author{
Larissa Ayane do Nascimento Braz ${ }^{1,2}$ (1); Nathan da Rocha Neves Cruz ${ }^{1}$ (D); Gabriel Fernando Müller Santos ${ }^{2}$ (1); \\ Larissa Fernandes Magalhães ${ }^{2}$ (D); Leandro Zuccolloto Crivellenti ${ }^{3}$ (D) \\ ${ }^{1}$ Universidade Estadual Paulista, Departamento de Clínica e Cirurgia Veterinária, Jaboticabal - SP, Brazil \\ ${ }^{2}$ Universidade de Franca, Programa de Pós-graduação em Ciência Animal, Franca - SP, Brazil \\ ${ }^{3}$ Universidade Federal de Uberlândia, Departamento de Clínica e Cirurgia Veterinária, Uberlândia - MG, Brazil
}

\begin{abstract}
Eosinophilic cystitis is a rare inflammatory disorder characterized by eosinophilic infiltration of entire layers of the bladder wall. The condition has been described in adults, children, and dogs. However, there are no consensus guidelines for the treatment of eosinophilic cystitis. Although human and veterinary literature reviews show some effectiveness in management with corticosteroids, antihistamines, and antibiotics, a variety of serious and frequent side effects are associated with steroid therapy. As a result, steroids are relatively contraindicated for patients with diabetes mellitus and Cushing's syndrome. A five-year-old neutered male chow-chow with controlled diabetes was referred with an 18-month history of malodorous urine, gross haematuria, and dysuria that were nonresponsive to antibiotics. The findings on general examination were unremarkable except for abdominal suprapubic discomfort. The complete blood count and biochemical profile (such as urea and creatinine) were normal except for mild peripheral eosinophilia. Although ultrasonography, bladder contrast radiography, and urine cytology findings indicated malignancy, with the presence of atypical urothelial cells, histopathology confirmed eosinophilic cystitis. Management with cyclosporine was adequate with complete remission of haematuria. This case report presents the first reported successful use of cyclosporine for the treatment of eosinophilic cystitis in a dog with diabetes.
\end{abstract}

Keywords: Cyclosporine. Enterobacter. Eosinophilia. Klebsiella pneumoniae. Multiple drug-resistance.

\section{RESUMO}

A cistite eosinofílica é uma doença inflamatória rara caracterizada por infiltração eosinofílica de todas as camadas da parede da bexiga. Essa enfermidade já foi descrita em adultos, crianças e cães. No entanto, não há um consenso de diretrizes sobre o seu tratamento. Mesmo que as literaturas humana e veterinária mostrem alguma eficácia no manejo com corticosteroides, anti-histamínicos e antibióticos, uma variedade de efeitos colaterais graves e frequentes está associada à terapia com esteroides. Dessa forma, o uso de esteroides é relativamente contraindicado para pacientes com diabetes mellitus e síndrome de Cushing, por exemplo. Um chow-chow, macho, castrado, de cinco anos e diabético estável foi encaminhado para atendimento com histórico de urina fétida, hematúria macroscópica e disúria não responsiva a antibióticos há 18 meses. A avaliação dos parâmetros físicos estava dentro dos padrões, exceto por desconforto abdominal suprapúbico à palpação. O hemograma e o perfil bioquímico (como a ureia e a creatinina) estavam dentro da normalidade para a espécie, exceto por eosinofilia periférica leve. Embora a ultrassonografia, a radiografia contrastada da bexiga e os achados da urinálise indicassem malignidade, com a presença de células uroteliais atípicas, a histopatologia confirmou o diagnóstico definitivo de cistite eosinofílica. O manejo com ciclosporina foi satisfatório, com ausência completa da hematúria. Este relato de caso apresenta o primeiro uso documentado de ciclosporina para o tratamento de cistite eosinofílica com sucesso em um cão com diabetes.

Palavras-chave: Ciclosporina. Enterobacter. Eosinofilia. Klebsiella pneumoniae. Multirresistência. 


\section{Correspondence to:}

Larissa Ayane do Nascimento Braz

Universidade Estadual Paulista, Departamento de Clínica e Cirurgia Veterinária

Via de Acesso Professor Paulo Donato Castelane Castellane

$\mathrm{S} / \mathrm{N}$ - Vila Industrial

CEP: 14884-900, Jaboticabal - SP, Brazil

e-mail: larissa-ayane@hotmail.com

Received: November 21, 2020

Approved: May 11, 2021

How to cite: Braz LAN, Cruz NRN, Santos GFM, Magalhães LF, Crivellenti LZ. Eosinophilic cystitis, a rare cause of persistent haematuria in a diabetic dog. Braz J Vet Res Anim Sci. 2021;58:e178389. https://doi.org/10.11606/ issn.1678-4456.bjvras.2021.178389

\section{Background}

Eosinophilic cystitis is a rare inflammatory disorder characterized by eosinophilic infiltration of entire layers of the bladder wall (van den Ouden, 2000). The condition has been described in adults, children, and dogs (Abilov et al., 2013; Choi et al., 2017; Evason \& Carr, 2007). The most common clinical signs of eosinophilic cystitis reported in the literature include pollakiuria, dysuria, haematuria, suprapubic pain, or urinary retention that mimic other inflammatory conditions (He et al., 2018; van den Ouden, 2000). The disease may also present with a bladder mass mimicking invasive bladder cancer in which case a biopsy is essential for accurate diagnosis (Shih et al., 2012). The differential diagnosis for eosinophilic cystitis includes transitional cell carcinoma, polyp, leiomyoma, fibrosarcoma, and myxoid sarcoma (Gelberg, 2010; Sykes \& Westropp, 2013; Yoon \& Hyun, 2012).

The cause and pathogenesis of the disease remain unclear (Choi et al., 2017). It is speculated that an antigenantibody complex is formed on exposure to antigens in the bladder. This IgE-mediated eosinophil activation leads to subsequent mast cell degranulation that elicits an inflammatory response that then attracts eosinophils. It is believed that interleukin 5 (IL-5) may contribute to local eosinophil recruitment, activation, and terminal differentiation of the eosinophil progenitors. Eosinophils can also release significant amounts of IL-5, leading to a positive feedback loop (Dubucquoi et al., 1994; Mosholt et al., 2014; Sparks et al., 2013; Teegavarapu et al., 2005).

Although there are no consensus guidelines for treatment of eosinophilic cystitis, human and veterinary literature reviews show some effectiveness in management with corticosteroids, antihistamines, and antibiotics (Evason \&
Carr, 2007; Shih et al., 2012), even in refractory cases (when eosinophilic cystitis progress to a diffuse and aggressive form), in which total cystectomy or partial resection of the lesion have been reported (Rossanese et al., 2019; Walker, 2018).

Additional modalities have also been used in the treatment of human eosinophilic cystitis cases, including surgery (suprapubic catheter, cystectomy, or urinary diversion), pharmacotherapy (nonsteroidal anti-inflammatories, cyclophosphamide, doxorubicin, cyclosporine, mitomycin, and bethanechol), hydrodistension, and radiotherapy (Abilov et al., 2013; Aleem et al., 2016; Park, 2017; Rossanese et al., 2019).

Steroids and antihistamines are the most used pharmacotherapies for eosinophilic cystitis. However, 20\% of patients are refractory to these agents. Besides, a variety of serious and frequent side effects are associated with steroid therapy, including Cushing's syndrome, osteoporosis, adrenal suppression, dyslipidemia, cardiovascular disease, increased insulin resistance, and hyperglycemia (Liu et al., 2013). As a result, steroids are relatively contraindicated for patients with diabetes mellitus and Cushing's syndrome (Liu et al., 2013). In these cases, cyclosporine has been reported as an appropriate alternative therapy for eosinophilic cystitis in humans (Aleem et al., 2016). This case report describes the first reported successful use of cyclosporine for the treatment of eosinophilic cystitis in a dog with diabetes.

\section{Case Presentation}

A five-year-old neutered male chow-chow with controlled diabetes presented with an 18-month history of malodorous urine, strangury, pollakiuria, gross haematuria, and dysuria. The referring veterinarian had last examined the dog one year before presentation. The patient was previously diagnosed with struvite urolithiasis, diabetes mellitus, and chronic hemorrhagic emphysematous cystitis based on urine culture (Klebsiella pneumoniae) and biopsies. The antibiogram showed significant antibiotic resistance.

After cystotomy and confirmation of struvite uroliths for one year, several antibiotics were used to treat the haematuria and clinical signs. The following antibiotics based on culture and antibiogram were used during this period: enrofloxacin, amoxicillin and clavulanate potassium, norfloxacin, nitrofurantoin, and cefaclor, without substantial improvement.

The dog's diabetes was treated and well-controlled with $0.5 \mathrm{U} / \mathrm{kg}$ every $12 \mathrm{~h}$ insulin NPH and diabetic food (Premier Diabetic ${ }^{\circ}$ ). The patient was up to date on rabies, canine distemper virus, canine adenovirus type-2, canine parvovirus, leptospirosis, canine coronavirus, and canine 
parainfluenza virus vaccinations. It had also recently been treated with a broad-spectrum anthelmintic.

The findings on general examination were unremarkable except for abdominal suprapubic discomfort during palpation. A complete blood count and biochemical profile, including total protein, albumin, globulin, albumin: globulin ratio, alanine aminotransferase (ALT), alkaline phosphatase (ALP), creatinine, urea, fructosamine, and glucose levels, were normal except for peripheral eosinophilia $(2645 / \mu \mathrm{L}$; reference range: $120-1800 / \mu \mathrm{L}$ ). Analysis of a urine specimen obtained by cystocentesis had a urine specific gravity of 1.024 , $\mathrm{pH} 6.0,3+$ protein, and gross macroscopic haematuria, with large amounts of white and red blood cells. Urine cytology showed squamous cells with some atypical urothelial cells. Eosinophiluria was not found. Ultrasound and contrast radiography findings showed bladder wall thickening with wall irregularities and the presence of a gas that was characteristic of emphysematous cystitis (Figures 1a and 1b).

On suspicion of malignancy, an exploratory laparotomy and bladder wall biopsy were performed (Figure 1c). An irregular thickened bladder wall was observed, and a fragment of suture (nylon) was removed. Multiple biopsy fragments were taken and submitted for histopathology.

Histopathologic examination showed a prominent urothelial mucosal hyperplasia, Bunn's nests, and mucosal ulceration. The submucosa was diffusely and severely oedematous, neovascularized, and primarily filled with eosinophils, lymphocytes, plasma cells, and fibroblasts (Figure 1d). All findings revealed eosinophilic cystitis.

Cultures of the bladder wall and urine samples indicated Enterobacter sp. and Klebsiella pneumoniae infections, respectively. Both organisms showed multidrug resistance with susceptibility to only ceftiofur, doxycycline, and cefovecin.

Medical management was performed with $7.5 \mathrm{mg} / \mathrm{kg}$ oral doxycycline every $12 \mathrm{~h}$ for 28 days and $7.5 \mathrm{mg} / \mathrm{kg}$ oral cyclosporine every $12 \mathrm{~h}$. Cyclosporine was initially discontinued after antibiotic use. However, clinical signs and haematuria returned within $48 \mathrm{~h}$. Therefore, cyclosporine therapy was reinitiated. Also, a complete blood count, biochemical profile, urinalysis, symmetric dimethylarginine, and ultrasonography were performed

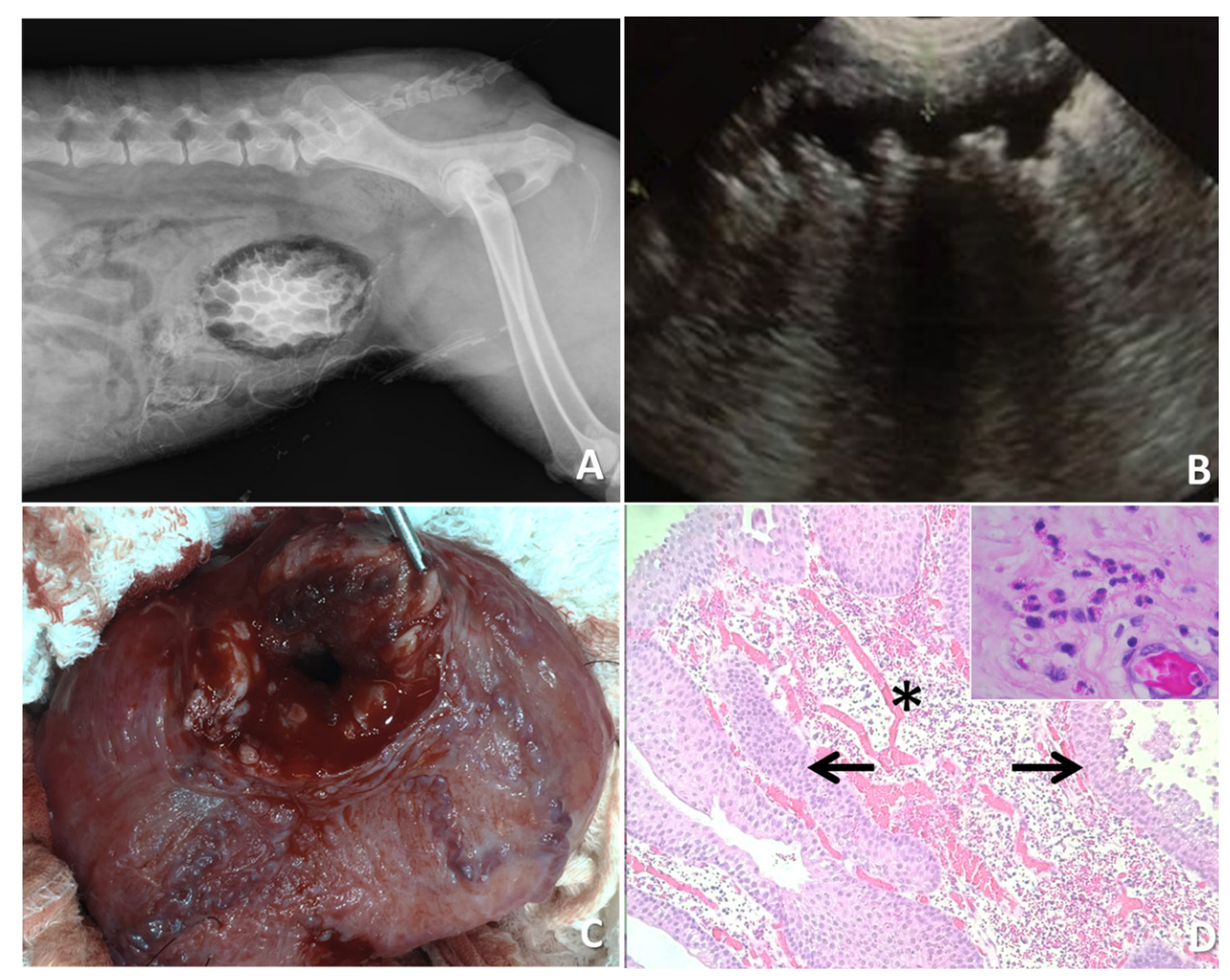

Figure 1-Findings from a 5-year-old male chow chow with eosinophilic cystitis. (a) Contrast radiography with irregular gas densities that can be seen throughout the urinary bladder wall; (b) Ultrasound examination of the markedly thickened urinary bladder $(0.7 \mathrm{~cm}$; reference range: $0.1-0.2 \mathrm{~cm})$ showing acoustic shadow artifacts on the wall with hyperechoic urinary bladder; (c) Markedly thickened urinary bladder; (d) Photomicrography, eosinophilic cystitis, dog. Urothelial mucosa hyperplasia with foci of invasion of submucosa forming nests (Brunn's nests - black arrow). In the submucosa, there is fibroblast proliferation with intense edema and moderate lymphoplasmacytic, eosinophilic inflammatory infiltrate, and neovascularization (black asterisk). Highlighted, eosinophilic inflammatory infiltrate. 100x and 1000x. H.E. 
every two months for monitoring. The exam findings remained stable, with 5 months postoperatively just one diagnosed urinary tract Klebsiella reinfection was treated with $10 \mathrm{mg} / \mathrm{kg}$ cefaclor every $8 \mathrm{~h}$ for two months. After eight months of use, cyclosporine withdrawal was attempted again but haematuria was identified after $48 \mathrm{~h}$. As a result, cyclosporine was restarted. Presently, the patient has had 13 months of follow-up with ongoing cyclosporine treatment and no clinical signs of urgency, frequency, or haematuria.

\section{Discussion and Conclusions}

Eosinophilic cystitis is rarely encountered in dogs or human beings and is likely misdiagnosed frequently, leading to delays in treatment (Abilov et al., 2013; Evason \& Carr, 2007; Walker, 2018). While the cause of eosinophilic cystitis remains elusive (Sparks et al., 2013), in humans it is believed to result from immune complex deposition in the bladder wall. It has been associated with many other disorders in human beings (He et al., 2018), including recurrent urinary tract infections, atopic diseases, chronic granulomatous disease, medications (oral or intravesical), parasitic infections, bladder neoplasms, interstitial cystitis, and foreign proteins (Runge et al., 2016). In dogs, it is strongly associated with urolithiasis (Evason \& Carr, 2007; Walker, 2018), as reported initially in this case.

Despite the initial presence of urolithiasis and a foreign body in the dog's bladder, these factors were likely not exclusively responsible for disease pathogenesis in this case. Even after the removal of these objects from the bladder, clinical signs were persistent and cyclosporine treatment was necessary. These findings suggest that other factors may have been associated with the perpetuation of the disease state in this dog, including diabetes mellitus.

Urolithiasis and bacterial cystitis may be secondary to diabetes mellitus. Systemic disorders, which cause a breakdown in host defense mechanisms, such as acute or chronic kidney disease, Cushing syndrome, diabetes mellitus, predispose to urinary tract infection (Sykes \& Westropp, 2013). The glucosuria, secondary to diabetes mellitus, predisposes the bacterial colonization, and the fermentation of glucose may uncommonly result in gas production, resulting in emphysematous cystitis (Sykes \& Westropp, 2013).

Gram-negative bacilli such as Klebsiella and Enterobacter are common pathogens involved in genitourinary tract infections (Sykes \& Westropp, 2013), especially in patients with diabetes mellitus. The relationship between genitourinary infections and eosinophilic cystitis has previously been reported in dogs (Evason \& Carr, 2007; Fuentealba \& Illanes, 2000). In the present case, infection with these microorganisms might have been associated with the chronic inflammatory state. However, this possibility was ruled out because antibiotics did not decrease the dog's haematuria or clinical signs of dysuria.

In humans, corticosteroids are the first-line agents for the treatment of eosinophilic cystitis (Evason \& Carr, 2007; Shih et al., 2012). However, in this case, cyclosporine therapy was chosen instead because of its proven efficacy in this disorder (Aleem et al., 2016), the relative contraindication to steroid (e.g., dyslipidemia, increased insulin resistance, and hyperglycemia) use in this diabetic patient (Liu et al., 2013), and its known association with reductions in serum levels of IL-4, IL-5, and IL-13 in humans (Aleem et al., 2016; Rush, 2013).

Long-term therapy with cyclosporine has been shown to cause renal toxicity in human beings (Rush, 2013). Measuring kidney function can be especially complicated in diabetic patients because the urine-specific gravity parameter may be altered by abnormal glucose levels and osmotic diuresis (Rave et al., 2006). As a result, creatinine, urinalysis, and symmetric dimethylarginine levels were also monitored for renal function assessments in this patient.

While it may be surprising that eosinophiluria was not identified during cytologic examination, eosinophils are rarely identified in the urinary sediment because of minimal mucosal shedding and their rapid destruction (Mosholt et al., 2014; Popescu et al., 2009). As a result, the diagnosis of eosinophilic cystitis can be difficult, especially with findings consistent with bladder cancer on cytology (Manimaran et al., 2013; Shih et al., 2012).

To conclude, the diagnosis of eosinophilic cystitis can be difficult when dogs present with bladder cancer cytology. Hence, histopathological examinations are of vital importance in these cases. Of note, cyclosporine can adequately manage this condition, especially in patients with diabetes mellitus who have contraindications to treatment with corticosteroids. Monitoring for potential adverse effects is needed.

\section{Conflict of Interest}

There is no conflict of interest between the authors or the participating institutions.

\section{Ethics Statement}

This study did not require official or institutional ethical approval. The animal was handled according to high ethical standards and national legislation. In addition, the owners of the canine patient provided written informed consent for publication of this case report. 


\section{References}

Abilov A, Ozcan R, Polat E, Dervişoğlu S, Emir H. Rare cause of dysuria: eosinophilic cystitis. J Pediatr Urol. 2013;9(1):e6-8. http://dx.doi.org/10.1016/j.jpurol.2012.04.005. PMid:22652390.

Aleem S, Kumar B, Fasano MB, Takacs E, Azar AE. Successful use of cyclosporine as treatment for eosinophilic cystitis: a case report. World Allergy Organ J. 2016;9:22. http:// dx.doi.org/10.1186/s40413-016-0113-4. PMid:27458500.

Choi MY, Tsigelny I, Boichard A, Skjevik ÅA, Shabaik A, Kurzrock R. BRAF mutation as a novel driver of eosinophilic cystitis. Cancer Biol Ther. 2017;18(9):655-9. http://dx.doi. org/10.1080/15384047.2017.1360449. PMid:28829677.

Dubucquoi S, Desreumaux P, Janin A, Klein O, Goldman M, Tavernier J, Capron A, Capron M. Interleukin 5 synthesis by eosinophils: association with granules and immunoglobulindependent secretion. J Exp Med. 1994;179(2):703-8. http:// dx.doi.org/10.1084/jem.179.2.703. PMid:8294877.

Evason MD, Carr AP. Eosinophilic cystitis in a female German wire-haired pointer. Can Vet J. 2007;48(5):50911. PMid:17542370.

Fuentealba IC, Illanes OG. Eosinophilic cystitis in 3 dogs. Can Vet J. 2000;41(2):130-1. PMid:10723601.

Gelberg HB. Urinary bladder mass in a dog. Vet Pathol. 2010;47(1):181-4. http://dx.doi.org/10.1177/0300985809353176. PMid:20080500.

He J, Ning F, Tu L, Hu J, Chen W, Zhao Y. Eosinophilic cystitis in children: a case report. Exp Ther Med. 2018;16(4):2978-84. http://dx.doi.org/10.3892/etm.2018.6578. PMid:30233669.

Liu D, Ahmet A, Ward L, Krishnamoorthy P, Mandelcorn ED, Leigh R, Brown JP, Cohen A, Kim H. A practical guide to the monitoring and management of the complications of systemic corticosteroid therapy. Allergy Asthma Clin Immunol. 2013;9(1):30. http://dx.doi.org/10.1186/17101492-9-30. PMid:23947590.

Manimaran D, Karthikeyan TM, Sreenivasulu M, Mrinalini VR, Gopinath V. Eosinophilic cystitis mimicking bladder tumour-a rare case report. J Clin Diagn Res. 2013;7(10):22823. PMid:24298501.

Mosholt KS, Dahl C, Azawi NH. Eosinophilic cystitis: three cases, and a review over 10 years. BMJ Case Rep. 2014;Oct 13;2014:bcr2014205708. http://dx.doi.org/10.1136/bcr2014-205708. PMid:25312971.

Park H. Eosinophilic cystitis with recurrent urinary retention: case report. Res Rep Urol. 2017;9:51-3. http:// dx.doi.org/10.2147/RRU.S129490. PMid:28357204.

Popescu O-E, Landas SK, Haas GP. The spectrum of eosinophilic cystitis in males: case series and literature review. Arch Pathol Lab Med. 2009;133(2):289-94. http:// dx.doi.org/10.5858/133.2.289. PMid:19195972.

Rave K, Nosek L, Posner J, Heise T, Roggen K, van Hoogdalem EJ. Renal glucose excretion as a function of blood glucose concentration in subjects with type 2 diabetes: results of a hyperglycaemic glucose clamp study. Nephrol Dial Transplant. 2006;21(8):2166-71. http://dx.doi.org/10.1093/ ndt/gfl175. PMid:16627603.

Rossanese M, Palumbo V, Sioletic S, Crestani A, Giannarini G, Ficarra V. Surgical treatment of eosinophilic systitis in adults: a report of two cases and a literature review. Urol Int. 2019;102(1):122-4. http://dx.doi.org/10.1159/000485257. PMid:29554647.

Runge SB, Høyer S, Winding L. Macroscopic hematuria and a bladder mass: eosinophilic cystitis in a 7-year-old boy. Case Rep Radiol. 2016;2016:9346218. http://dx.doi. org/10.1155/2016/9346218. PMid:27340584.

Rush D. The impact of calcineurin inhibitors on graft survival. Transplant Rev (Orlando). 2013;27(3):93-5. http:// dx.doi.org/10.1016/j.trre.2013.04.003. PMid:23743217.

Shih M-T, Cha T-L, Sun G-H, Yu D-S, Tsao C-W. Eosinophilic cystitis simulating invasive bladder cancer: report of a case and review of the literature. J Med Sci. 2012;32:139-42.

Sparks S, Kaplan A, DeCambre M, Kaplan G, Holmes N. Eosinophilic cystitis in the pediatric population: a case series and review of the literature. J Pediatr Urol. 2013;9(6 Pt A):738-44. http://dx.doi.org/10.1016/j.jpurol.2012.11.004. PMid:23391564.

Sykes JE, Westropp JL. Bacterial Infections of the Genitourinary Tract. In: Sykes JE, editor. Canine and feline infectious diseases. St. Louis: Saunders; 2013. p. 871-85.

Teegavarapu PS, Sahai A, Chandra A, Dasgupta P, Khan MS. Eosinophilic cystitis and its management. Int J Clin 
Pract. 2005;59(3):356-60. http://dx.doi.org/10.1111/j.17421241.2004.00421.x. PMid:15857336.

van den Ouden D. Diagnosis and management of eosinophilic cystitis: a pooled analysis of 135 cases. Eur Urol. 2000;37(4):38694. http://dx.doi.org/10.1159/000020183. PMid:10765067.

Walker MA. Struvite urolithiasis with eosinophilic polypoid cystitis in a shih tzu dog. Can Vet J. 2018;59(2):181-3. PMid:29386681.
Yoon WK, Hyun C. Eosinophilic polypoid cystitis in a cocker spaniel dog. J Vet Clin. 2012;29:247-9.

Financial Support: Larissa Ayane do Nascimento Braz was financed in part by the Coordination for the Improvement of Higher Education Personnel (CAPES), Brazil - Finance code 88887.339240/2019-00. 